\title{
Champions From The Land Of The Colonias: Lessons For Collaborative Learning From A National Championship Accounting Team
}

John Darcy, (Email: johndarcy@utpa.edu), The University of Texas-Pan American Delia Gutierrez-Sanchez, The University of Texas-Pan American Mariela Molina, The University of Texas-Pan American

\begin{abstract}
This case study compares the experiences of Hispanic students in their competition against teams from the nation's top research schools with their experiences in regular classroom small-group learning projects.
\end{abstract}

\section{INTRODUCTION}

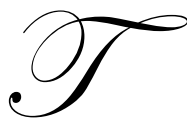

he area of South Texas near the Rio Grande is called The Valley and includes the poorest counties in the U.S., the closest thing to third world conditions to be found in this country. This paper examines the experiences in collaborative learning of a group of students from a Hispanic Serving Institution $(\mathrm{HSI})^{1}$ located in a Valley county that historically has had the lowest per capita income in the United States and the highest unemployment rate in Texas. Over a third of the county's people, many of whom are migrant farm workers, live in colonia communities where inadequate water supplies and substandard housing are rife.

For two years in a row, 2004 and 2005, accounting teams from a public four year university in The Valley has won first place in the National Case Study Competition sponsored by KPMG, one of the largest accounting firms in the world, and the Association of Latino Professionals in Finance and Accounting (ALPFA). Teams in the competition are comprised of approximately $80 \%$ Latino accounting majors with curriculum to support sitting for the CPA exam upon graduation. The flagship research universities from the three U.S. states with the highest Hispanic populations, the University of California-Berkeley, the University of Texas-Austin, and the University of Arizona, competed in the competition as did the flagship research university from the state with the highest Hispanic percentage population, the University of New Mexico. Other top research universities in the competition included New York University, the University of Massachusetts-Amherst, the University of Southern California, and the University of Washington-Seattle.

This case study compares the experiences of the students in their competition against teams from the nation's top research schools with their experiences in regular classroom small-group learning projects. Case studies of this kind detailing small-group processes and procedures are needed to provide a link between practice and research work so that successful experiences may add to the body of knowledge leading to improved quantitative and qualitative methods and provide inspiration for replicable models. As one group of researchers noted: (Springer et al. (1999):

Perhaps the most important component of future analyses is the need for more detailed descriptions of small-group processes or procedures by investigators or instructors who report research on the effects of their work. What was done that can be replicated?

\footnotetext{
${ }^{1}$ Hispanic-serving institutions (HSIs) are degree-granting public or private institutions of higher education eligible for Title IV funding in the United States and Puerto Rico in which Hispanics comprise 25 percent or more of the undergraduate full-time-equivalent enrollment.
} 
In interviews with the media after their victory the students cited a number of factors contributing to the victory. Team members said the time commitment during the three-month preparation for the competition was challenging. "After our first meeting we first practiced for two hours three times a week, then the last month it was almost every day even Saturdays and Sundays," one member said. Faculty support was provided by an advisor from the accounting department and another faculty member from the communications department who advised on presentation skills. Interestingly, student comments focused primarily on the confidence that each of these the faculty instilled in the students rather than technical or informational contributions. According to team members, the accounting faculty advisor "never stopped believing in us" and the communications professor "was inspiring and motivated us to the extreme."

Judges at the competition included the Inspector General of the U.S. Government's General Accounting Office and senior partners from national CPA firms. The judges noted that the team's demonstrated depth of research, professionalism, and passion played roles in their victory. The team felt that "one of the strengths in our presentation was that we went above and beyond, we took on the role of professional CPA's." One of the judges said afterwards that the team presented better than some of the professionals at the event. Judges also noted that the team's presentation was "from the heart" and "passionate." The judges were also impressed with the consistency of the strength of presentation by each of the team members. Each of the team members made a strong presentation, with no let down in quality as the presentation proceeded. The team members each had a specific area of responsibility in the presentation and agreed that they were balanced in their abilities. "We all have different personalities but we were each strong in our own way," said one team member.

The factors cited by the judges and team members for the success of the team parallel those in prior research that distinguish successful teams. Analyzing the intangible factors that allow the skills, knowledge and expertise of individual members complement and enhance the performance of the whole group is an important topic for research.

Various constructs have been identified as contributing to the success of collaborative learning. Felder et al. $(2000,1999,1994)$ focus on five factors which are summarized by Pimmel (2003) as (1) positive interdependence: achieving the goal requires everyone's involvement, and if anyone fails to do his or her part, everyone suffers, (2) individual accountability: everyone is responsible for doing his or her work and for understanding everyone else's work, (3) face-to-face, promotive interaction: some of the work must be done interactively where team members provide each other questions, feedback, and instruction, (4) use of interpersonal and teamwork skills: members need leadership, communication, conflict resolution, and time management skills and (5) regular self-assessment of team: teams should examine themselves to determine what they are doing well and what needs improvement. Larson and LaFasto (1989) in their ground-breaking study of successful teams identified eight characteristics of effectively functioning teams: (1) a clear, elevating goal, (2) results-driven structure, (3) competent team members, (4) unified commitment, (5) collaborative climate, (6) standards of excellence, (7) external support and recognition, and (8) principled leadership.

However, substantial obstacles can interfere with the development of a successful group effort. Sorenson (1981) uses the term "grouphate" to describe the discomfort for the group process arising within ineffective groups. According to Yamane (1996) the two most frequently cited reasons for grouphate are free-rider problems and various organizational concerns centered on transaction costs. Free rider problems occur when students perceive the group project as a kind of public good where personal cost can be avoided while retaining the benefits of a high grade through the efforts of other students (McKinney and Graham-Buxton 1993; Olson 1965; Rau and Heyl 1990). Transaction costs describe the additional effort involved in interacting and collaborating with other members of the group, including time spent in scheduling and meeting as a group, negotiating differences of opinion in developing and preparing a project, and assigning individual task assignments.

\section{RESEARCH METHODOLOGY}

Unlike many papers that focus on the role of the instructor, this study looks explicitly at the differing experiences of the students in regular classroom group projects and in their national case study competition. Demographic information is provided for each student including age, race, gender, and academic performance as indicated by cumulative grade point average through the 2004 Fall Semester. 
Initial responses are obtained by asking the championship team students to complete a survey asking them to first evaluate various aspects of their regular group learning experiences using a five-point Likert scale. Each of the questions were rated on a 5-point scale ranging from "strongly disagree" (1) to "strongly agree" (5). The courses and instructors involved in the regular group learning experiences are to some extent common among the championship team students, but some differences exist. Overall, the regular group learning experiences are sufficiently comprehensive and varied to be considered a fairly reliable representation of the group learning experience in their college. The students are then asked to complete the same survey based on their championship team experiences. This is followed up with personal interviews and direct quotations are used in order to more directly present the student experience (Maguire and Edmondson 2001). Survey data for the regular group learning experiences cover the period from the 2003 Fall Semester through the 2005 Fall Semester. The championship team experience occurred during the 2005 Spring and Summer Semesters.

The positive characteristics of effectively functioning teams identified by Felder et al., and Larson and LaFasto and the negative characteristic identified by Yamane are used as starting points to identify latent endogenous variables characterizing the students' attitudes and opinions as reflected in their survey responses. Tests of significant differences in responses to questions regarding regular group learning and the championship team experience are evaluated using analysis of variance and Pearson's chi-square (Clason and Dormody, 1994, Feinberg 1977). Conclusions derived from the surveys and interviews provide the basis for recommendations on how to carry over the championship group learning experience into the classroom.

\section{DESCRIPTION OF THE CASE STUDY SUBJECTS}

Participants in the KPMG-ALPFA National Case Study Competition are required to be actively enrolled students who maintain a minimum 3.2 grade point average. Teams should be at least $80 \%$ Latino students and $80 \%$ accounting majors studying in a curriculum sufficient to support sitting for the CPA exam.

The subjects of this case study are five Latino undergraduate students at a Hispanic Serving Institution located in the Rio Grande Valley. They are all accounting majors and expect to sit for the CPA exam upon completion of their studies. The student's grade point averages range from 3.5 to 3.9 .

Demographic information for each student including age, race, gender, language and academic performance as indicated by cumulative grade point average through the 2004 Fall Semester is provided in Table 1.

\begin{tabular}{|c|c|c|c|c|c|c|}
\hline \multicolumn{7}{|c|}{ Table 1: Demographic Information for Subjects } \\
\hline Student & Age & Race & Gender & $\begin{array}{c}\text { Primary } \\
\text { Language }\end{array}$ & $\begin{array}{c}\text { Secondary } \\
\text { Language }\end{array}$ & GPA \\
\hline A & Under 25 & Latina & Female & Spanish & English & 3.5 \\
\hline B & Under 25 & Latina & Female & Spanish & English & 3.9 \\
\hline C & Under 25 & Latina & Female & Spanish & English & 3.8 \\
\hline E & Over 25 & Latina & Female & Spanish & English & 3.5 \\
\hline F & Over 25 & Latina & Female & English & Spanish & 3.8 \\
\hline
\end{tabular}

All but one of these students' primary language is Spanish and has mastered English as a second language. None of the parents of these students has graduated from college, although four of the ten parents have some college experience. The grandparents of these students generally received little or no formal education. In their demographic questionnaires each student was asked to briefly state what motivated them to succeed. Remarkably, four of the five stated their primary motivation was to provide a role model for others. The other student said she was motivated by her mother's experience as an immigrant - that is, a role model that influenced her. 


\section{DESCRIPTION OF THE CHAMPIONSHIP TEAM AND CLASSROOM GROUP EXPERIENCES}

The team competition experience lasted from May to August 2005, a time roughly equivalent to a semester. Team members were all volunteers and were self-selected by consensus decision with participation from the faculty advisor. The team was assigned a unique case, which was researched and to which relevant and practical accounting guidance was applied to develop a solution. At the competition, the case solutions were presented to the panel of judges consisting of KPMG partners and executive level ALPFA members. Faculty advisors included a member of the accounting faculty and a professor of communications who helped the team with their presentation skills.

The classroom group learning experiences described in this research vary from student-to-student, but represent a common pool of experience. Professors generally assign a group project and either select groups or allow self-selection. Students are responsible for scheduling meetings and completing projects on time. Motivation is primarily based on the course grade. During the group experience faculty generally do not provide feedback on an ongoing basis, but do respond to questions when asked.

\section{DESCRIPTION OF THE SURVEY INSTRUMENT}

The students were asked to complete a series of 63 questions describing various aspects of their regular classroom group learning experiences using a five-point Likert scale. Each of the questions were rated on a 5-point scale ranging from "strongly disagree" (1) to "strongly agree" (5). The questions contained in the instrument are included in the "Question" column of the Appendix. Students first completed the survey based on their experiences with the championship team and then repeated the survey based on their experiences in regular classroom group learning projects.

Questions are assigned to nine types based on the eight characteristics of effectively functioning teams identified by Larson and LaFasto (1989) and an additional category relating to overall satisfaction with the group learning experience.
(A) A clear, elevating goal,
(B) Results-driven structure,
(C) Competent team members,
(D) Unified commitment,
(E) Collaborative climate,
(F) Standards of excellence,
(G) External support and recognition,
(H) Principled leadership, and
(I) Satisfaction with the group learning experience.

\section{RESULTS OF THE SURVEY}

Table 2 provides combined results from the Likert scale surveys for each question type. The results for each individual question are found in the Appendix. Table two ranks the question type results by the mean difference in responses between the championship team and regular classroom group learning experiences. These ranking highlights the areas where the widest differences in the perceived quality of the students' experience occur. Interpretation of the significance of Likert-scale data is problematic, particularly when small samples are used (Clason and Dormody, 1994). In this case study the differences in responses between the team competition and classroom groups experience were apparent from a question-by-question analysis of the questionnaires. Computed $t$ and Pearson chi-square statistics ${ }^{2}$ reported in Table 2 are all significant as are the overwhelming majority of the results on a question-by-question basis reported in the Appendix.

\footnotetext{
${ }^{2}$ Chi-square statistics were computed using the Pearson chi-square, the continuity adjusted chi-square, and likelihood ratio chi-square procedures with similar results.
} 
Table 2: Analysis of Variance Between Championship Team and Classroom Group Learning Experiences $1=$ strongly disagree, $2=$ disagree, $3=$ not sure, $4=$ =agree, $5=$ strongly agree

\begin{tabular}{|c|l|c|c|c|c|c|c|c|}
\hline Type & \multicolumn{1}{|c|}{ Factor } & $\mathbf{N}$ & $\begin{array}{c}\text { Mean: } \\
\text { Team }\end{array}$ & $\begin{array}{c}\text { Mean: } \\
\text { Groups }\end{array}$ & $\begin{array}{c}\text { Mean } \\
\text { difference }\end{array}$ & t Stat & $\begin{array}{c}\text { P(T<=t) } \\
\text { one-tail }\end{array}$ & Chi-sq. \\
\hline C & $\begin{array}{l}\text { Competent team } \\
\text { members }\end{array}$ & 35 & 4.486 & 2.514 & 1.971 & 9.526 & 0.000 & 16.427 \\
\hline H & Principled leadership & 30 & 4.533 & 2.600 & 1.933 & 10.802 & 0.000 & 5.236 \\
\hline F & $\begin{array}{l}\text { Standards of } \\
\text { excellence }\end{array}$ & 10 & 4.800 & 3.100 & 1.700 & 4.295 & 0.001 & 2.431 \\
\hline B & $\begin{array}{l}\text { Results-driven } \\
\text { structure }\end{array}$ & 60 & 4.100 & 2.567 & 1.533 & 8.741 & 0.000 & 21.469 \\
\hline G & $\begin{array}{l}\text { External support and } \\
\text { recognition }\end{array}$ & 15 & 4.667 & 3.000 & 1.467 & 4.560 & 0.000 & 4.823 \\
\hline A & A clear, elevating goal & 15 & 4.800 & 3.467 & 1.333 & 4.000 & 0.001 & 4.062 \\
\hline E & Collaborative climate & 55 & 4.545 & 3.236 & 1.309 & 8.423 & 0.000 & 22.808 \\
\hline D & Unified commitment & 65 & 4.308 & 3.123 & 1.185 & 7.573 & 0.000 & 16.957 \\
\hline & $\begin{array}{l}\text { Satisfaction with the } \\
\text { group learning } \\
\text { experience. }\end{array}$ & & & & & & & \\
\end{tabular}

a Type: Questions are assigned to nine types based on the eight characteristics of effectively functioning teams identified by Larson and LaFasto (1989) and an additional category relating to overall satisfaction with the group learning experience.

b Satisfaction with the group learning experience represents an outcome and is not ranked with the characteristics of effectively functioning teams factors.

${ }^{\mathbf{c}}$ Indicates chi-square tests significant at the $1 \%$ level. The widest gap in Table 2 is found in responses involving competency of team members followed by principled leadership, standards of excellence, and results driven structure.

\section{Competent Team Members}

Questions in this category involved the criteria for selection of team and group members, their skill levels, the roles that they assumed during the project, and how well they completed assigned tasks. The large gap between the team and classroom experiences in this category is due more to the negative responses by the students to the classroom group experience rather than to the highly positive responses to the team experience. Particularly low responses for the classroom group experience were received in response to questions regarding whether classroom group members had the personal characteristics required to achieve excellence while working well with others and whether the classroom group was organized by selecting people who were best equipped to achieve the team's objective.

During one-on-one interviews the students were asked to define characteristics that should be expected and required in selecting competent team members. Grade point average was the major characteristic mentioned by the students who believe that it demonstrates determination, commitment, and competence. They welcomed the idea of professors selecting groups based on similar grade point averages because they tended to view low grade averages as an indicator of free-rider problems. Another indictor or competency mentioned by the students was personal maturity. They felt that the members of the competition team demonstrated this trait and were comfortable making and receiving criticisms and observations in order to achieve the objective. This dynamic of personal maturity and the ability to engage in give and take of constructive criticisms is generally lacking in the classroom group setting.

\section{Principled Leadership}

The principled leadership factor involved two main constructs in this study, student leadership and faculty interaction. Responses to three questions regarding faculty interaction seems to play a larger role in accounting for the mean differences in this category as a whole, contributing about $50 \%$ more to the observed mean differences than the three questions regarding student leadership within the team or group. 
In interviews the team members indicated that the presence of leader was a prime determining factor for the team's success. But the championship team had a wider, almost unique concept of shared leadership. As one team member stated, "In the championship team experience, all of us served the role of a leader." One student on the competition team was early on assigned the role of "straw boss," who organized meeting times and made sure each team member was current on assigned tasks. In the presentation, a different student took on the role of the "engagement partner," nominally responsible for the entire project as presented to the judges. Other students took on the roles of "audit managers" and "tax managers." The students noted that these roles were functional and never connoted any particular status higher or lower than other members of the team. However, in the general classroom setting leadership was associated with a need for control. As one student stated, "I knew I always served the role of leader because I cared about my grade."

Regarding faculty interaction, major differences were encountered between the championship team and classroom group experiences as illustrated by students' comments. "Faculty motivation and guidance played a huge role in the performance of the championship team, but in the class room setting faculty generally played a minimal role." "Classroom group experiences were very different from the championship team experience. Generally the only involvement faculty had in the classroom group projects was if the students themselves asked questions. Even then, their role was minimal."

\section{Standards Of Excellence}

The high mean difference between the team and classroom experience in this category is driven by the highest positive mean response in any category for the team competition. The students felt strongly that the championship team had a sense of honor and integrity and recognizable standards of excellence placing this category of responses at the top of their ranked responses. This category of questions was only slightly positively rated for the classroom group experience, ranking fifth out of the eight categories, and indicating a sense of indifference to standards of excellence in classroom group projects.

Students complain that they receive mixed signals from faculty regarding standards for classroom group projects. Often they feel that professors assign group projects to lighten their teaching responsibilities. More significantly, students complain that professors shift the responsibility for policing the behavior of poor performing students on to them. One student provided an example of a group that was punished when one member was discovered to have plagiarized material for a project. Objections by the students were dismissed under a theory of group responsibility and the students "should have known of the plagiarism." The students in this case study feel that in the classroom setting group projects involve a division of labor and students do not have the experience or training that enables them to police the work of other students. This incident has created a feeling of distrust for group work not only by the student affected, but by other students aware of it.

\section{Results-Driven Structure}

The questions in the category dealt with the structure and efficiency of the projects and addresses the "transaction costs" problem described by Yamane (1996). This category elicited some of the lowest responses regarding the classroom group learning experience, while except for one question regarding keeping minutes of meetings, the responses for the championship team were of a high level consistent with their responses in other categories.

In the follow-up interviews, the team members indicated that the championship team was better organized than their classroom group experiences. While working on the championship team, the students met continuously and for long periods of time. "After our first meeting we first practiced for two hours three times a week, then the last month it was almost every day even Saturdays and Sundays," one team member explained The meetings included assigning roles, preparing different assignments, and practicing their presentations. For the championship team, one student was given the role of the audit partner, three were audit managers, and one was a tax manager. 
The team members indicated the structure of the championship team was more organized compared to classroom groups. The interviewees had problems with classroom groups. The main challenge that was mentioned was time scheduling. It was always difficult for everyone to meet at the same time. One team member expressed the belief that classroom group projects were counterproductive due to numerous time conflicts resulting in inefficiencies and wasted time. Although, the championship team members faced the same difficulties as in the classroom projects, scheduling conflicts were not a problem. A team member thought that the competition team members put more effort into overcoming problems with scheduling and time conflicts because of the greater motivation of the students and the greater understanding of the benefits from the activity.

\section{A Clear, Elevating Goal}

The responses by the students in this category represented the highest ranking for both the competition team and the classroom group learning experience, considerably above their mean responses for all categories of questions in both questionnaires. But while the responses regarding the team competition were strongly positive (averaging 4.8), they were much lower for the classroom group learning experience (averaging 3.467). "I had a clear understanding of the goal to be achieved" was the single most positively rated question in the classroom group learning questionnaire, the only question that the students clearly agreed to (averaging 4.0) among the classroom group questions.

Comments from the competition team members indicated a clear sense of purpose. "We all had a goal and we all wanted the same thing. We were determined and we all worked together for it. So I think that's one of the things that made a difference... having the same state of mind." Another team member said, "We had a positive attitude. We were focused and committed to do the best. We also tried to help each other so everyone would understand the concept and everyone worked as one." The dedication and goal orientation exhibited by the competition team members were absent in the classroom group setting and were unpleasant by comparison; dissimilar goals, individual goal conflicts, and free riders among other factors impeded unity of purpose. The free rider problem came up time and again in the students comments regarding the classroom group experience.

\section{External Support And Recognition}

For the team competition, the students felt very positive about external support and resources provided to them. In the context of the classroom group experience, the students were indifferent to this factor (averaging 3.0). The students mildly indicated agreement that they received the resources needed to get the job done the classroom experience, but felt they lacked support from persons or agencies outside the team who were capable of contributing to the success of the project.

Remarking on the championship team experience, the students indicated that they had all the resources they needed to get the job done. "All the resources we needed were available. For example, if we needed software, the PowerPoint projector, a remote control device, use of the faculty lounge, and other resources, they were all provided for us." Comments for the classroom group experience were completely different. A team member noted, "frequently classroom groups can't perform up to their potential due to a lack of resources . . . In one of my classroom group experiences, a professor assigned group work where specific software had to be utilized and the software was only available in one lab at the university. It was very difficult to find available spaces at the lab and since the project had to be done in a week, the group was only able to complete $90 \%$ of the work."

These comments are remarkable. The resources made available to the championship team are commonly available without additional costs in the college setting. Making them available to the students required a small amount of administrative effort by faculty. In the classroom setting, the students seemed to feel that faculty were indifferent to the "transaction costs" being incurred by the students in getting the project completed. 


\section{Unified Commitment}

The responses to this group of questions elicited a wide range of responses for the class group project experience, while the responses were uniformly high for the team competition (averaging 4.3 overall). In the classroom group experience students tended to feel negatively about the equality of creative contributions made to the project (averaging 2.6) but were more positive about the collaborative environment (averaging 3.6) and the effective subdivision of work (averaging 3.8). Overall, however, the students were not sure if the group worked effectively together (averaging 3.0). In contrast, the competition team strongly agreed that the team worked effectively together (averaging 4.8).

The students in this case study generally believe that classroom groups lack unified commitment by the members. A number of unsatisfactory experiences in the classroom group setting have discouraged these students. Again the free rider problem erodes the sense of loyalty and commitment in the classroom setting. One team member recalls being penalized for an act of plagiarism committed by a classroom group member. Such events can create an atmosphere of distrust in which unity of purpose is difficult to achieve. In contrast to the classroom group experience, all team members agreed that there was a high degree of loyalty and commitment in the competition team. A team member said, "We seemed to hit it off. Dedication was there. We all fed off each other to make everything work." "The team became more like a family." The team members created an atmosphere of support and trust that carried them through the competition and the relationships forged during that time have continued after the competition.

\section{Collaborative Climate}

The competition team expressed exceedingly strong agreement that a sense of loyalty and commitment existed within the team (averaging 4.8) and that there was an unrestrained sense of enthusiasm and excitement about the endeavor (averaging 4.8). These sentiments were not matched by the classroom where questions involving loyalty and commitment and a sense of enthusiasm and excitement averaged only 2.6, indicating the students did not believe that these factors were present.

Team members commented that during the championship project they developed a sense of loyalty and commitment. One team member stated that "although we had different personalities we were very open and shared our opinions with each other and that enabled us to see the big picture." The shared desire to do well in the competition seemed to provide the incentive to commit to the project. In classroom group work, a lack of such commitment is evident from the students" comments. "Some students are not really committed, they just want to get it done without worrying about the outcome." For these students it appears that a collaborative climate was an extension of the unified commitment discussed above.

\section{Satisfaction With The Group Learning Experience}

Overall satisfaction with the team experience is evident from the responses of the competition team who expressed a strong desire to work with the same group again based on the team experience viewed group work as very positive. But the same students indicate a tendency to prefer to work alone on their next project and a lack of enjoyment when responding to the classroom experience. The capstone question in this research is "working as a team on this project was a positive experience." The competition team averaged 4.8, indicating strong agreement, while the same students responding to the classroom group learning experience averaged only 3.0 , indicating indifference.

During the follow-up interviews, the students were asked to summarize their group experiences in both the championship team and general classroom settings. One team member noted, "My experience with the championship team was unlike any other. Trust, integrity, collaboration, and commitment were all present enhancing the group experience. In the general classroom setting, however, the same collaborative climate and sense of commitment was not felt." The team members primarily found the differing goals among students in the general classroom to significantly impair the group's performance attributing to their lack of desire to work with the same group again. For 
the championship team, the opposite was true; the alignment of goals and continuous collaboration and commitment attributed to their strong desire to work with the same group again and to provide role models to other students.

The sincerity of the students' stated desire to continue to work with members of the championship team and to provide role models has been borne out by subsequent events. Following their victory in the 2005 KPMG \& ALPFA National Case Study Competition the team members made a video recording of their presentation for use by future teams. One of the team members decided to prepare a guide for future teams as a Honors Program project, a project that provided early inspiration for this research. These students also established an ALPFA chapter at their school and began to provide the first free CPA exam preparation course in the region. These students are using their accounting skills to give back to their community and combat the Rio Grande Valley's low passing rate for the Certified Public Accounting exam.

\section{CONCLUSIONS}

The overriding message received from the students in this case study is that with proper motivation and guidance from faculty group learning can be a richly rewarding experience. The students in this case study faced a similar, set of problems and obstacles during a team competition project as they did during regular class group projects. However, their attitudes toward these experiences are remarkably different. Transaction costs were a major factor in both experiences, but during the team competition the students were motivated to put effort into overcoming these problems because of the perceived benefits from the activity and because of external support from faculty. Free riding, a substantial problem cited by each of the students during regular class projects, did not exist during the team competition. They believe that the voluntary nature of the activity and use of grade point averages (required under the terms of the competition) to select the competition team eliminated the free rider problem.

Several important lessons for faculty emerge from this study. First, students do not feel that they can effectively police the behavior of other members of a group and resent being held responsible for actions over which they have no control. The free rider problem is the most commonly encountered version of this problem, but it also extends to group responsibility for such behavior as plagiarism. Instructors need to recognize this as a substantial issue that needs to be effectively addressed at the faculty level.

Faculty should also make an effort to convey to students that external resources are available to them and ensure that the use of necessary resources will not entail excessive transaction costs on the part of the students. The external resources used by the team competition students in this case study were easily available and required only a few minutes of faculty time to arrange, but made a vast difference in the ability of the students to complete their tasks efficiently. Faculty should be proactive in seeking input from students on the resources needed to complete their tasks and difficulties the students are encountering in making use of those resources during the assignment.

The experiences outlined in this case study suggest that students can create a positive learning experience among themselves if given the proper motivation and if not hampered by free riding. The motivation provided by the team competition should not be considered a unique distinguishing factor. The market for graduates, competition for grades, and opportunities to work with talented faculty members should be able to provide equal or superior motivating factors. Faculty members play a critical role in providing this motivation and creating a positive learning environment and most importantly a sense of trust.

\section{REFERENCES}

1. Clason, D.L. and Dormody, TJ. 1994. Analyzing data measured by individual Likert-type Items. Journal of Agricultural Education 35 (No. 4): 31-35.

2. $\quad$ Feinberg, R.V. 1977. The Analysis of Cross-classified Categorical Data. Cambridge, MA: MIT Press.

3. Felder, R. M., D. R. Woods, J. E. Stice, and A. Rugarcia. 2000. The future of engineering education: II Teaching methods that work. Journal of Chemical Engineering Education 24 (No. 1): 26-39.

4. 21 and R. Brent. 1999. How to improve teaching quality. Quality Management Journal 6 (No. 4): 9 
5. and R. Brent. 1994. Cooperative learning in technical courses: Procedures. pitfalls, and payoffs. U.S. Dept. of Education, Washington, D.C., ERIC Document Reproduction Service Rep. ED 377038.

6. Larson, C.E. and F.M.J. LaFasto. 1989. Teamwork: What Must Go Right/What Can Go Wrong. Newbury Park, CA: SAGE Publications.

7. Maguire, S. and S. Edmondson. 2001. Student evaluation and assessment of group projects. Journal of Geography in Higher Education 25 (No. 2): 209-217.

8. Pimmel, R.L. 2003. A practical approach for converting group assignments into team projects. IEEE Transactions On Education 46 (No. 2, May): 273-282.

9. Sorensen, S. 1981. Grouphate. Paper presented to International Communication Association Annual Convention. Minneapolis (May 1981).

10. Springer, L., M.E. Stanne, and S.S. Donovan. 1999. Effects of small-group learning on undergraduates in science, mathematics, engineering, and technology: A meta-analysis. Review of Educational Research 69 (No. 1, Spring): 21-51.

11. Yamane, D. 1996. Collaboration and its discontents: Steps toward overcoming barriers to successful group projects. Teaching Sociology 24 (No. 4, October): 378-383.

12. McKinney, K. and M. Graham-Buxton. 1993. The use of collaborative learning groups in the large class: Is it possible? Teaching Sociology 21:403-408.

13. Olson, M. 1965. The Logic of Collective Action. Cambridge, MA: Harvard University Press.

14. Rau, W. and B. Heyl. 1990. Humanizing the college classroom: Collaborative learning and social organization among students. Teaching Sociology 18:141-55.

\section{APPENDIX: Analysis Of Variance Between Championship Team And Classroom} Group Learning Experiences

\begin{tabular}{|c|c|c|c|c|c|c|c|}
\hline Type $^{\text {a }}$ & Question & $\begin{array}{l}\text { Mean: } \\
\text { Team } \\
\text { Compet } \\
\text {-ition } \\
\end{array}$ & $\begin{array}{l}\text { Mean: } \\
\text { Class } \\
\text { Groups }\end{array}$ & $\begin{array}{l}\text { Mean } \\
\text { Differ- } \\
\text { ence }\end{array}$ & t-stat & $p$ & Chi-sq \\
\hline $\mathrm{C}$ & $\begin{array}{l}\text { The group/team was organized by selecting } \\
\text { people who were best equipped to achieve } \\
\text { the team's objective. }\end{array}$ & 4.6 & 2 & 2.6 & 10.614 & 0.000 & 0.082 \\
\hline $\mathrm{H}$ & $\begin{array}{l}\text { There was substantial faculty interaction } \\
\text { with this group project. }\end{array}$ & 4.6 & 2 & 2.6 & 10.614 & 0.000 & 0.082 \\
\hline $\mathrm{C}$ & $\begin{array}{l}\text { The group/team members had the personal } \\
\text { characteristics required to achieve } \\
\text { excellence while working well with others. }\end{array}$ & 4.8 & 2.2 & 2.6 & 3.833 & 0.009 & 1.967 \\
\hline $\mathrm{B}$ & We had an agenda for each meeting. & 4.2 & 1.8 & 2.4 & 3.539 & 0.012 & 2.324 \\
\hline $\mathrm{D}$ & $\begin{array}{l}\text { There were no significant conflicts } \\
\text { between individual and team goals. }\end{array}$ & 4.6 & 2.2 & 2.4 & 9.798 & 0.000 & 0.194 \\
\hline $\mathrm{H}$ & $\begin{array}{l}\text { Faculty seemed to be highly interested in } \\
\text { personally motivating the team members. }\end{array}$ & 4.6 & 2.2 & 2.4 & 9.798 & 0.000 & 0.194 \\
\hline $\mathrm{B}$ & $\begin{array}{l}\text { Our meeting stayed focused and made } \\
\text { effective use of time. }\end{array}$ & 4.4 & 2.2 & 2.2 & 2.994 & 0.020 & 3.050 \\
\hline $\mathrm{H}$ & $\begin{array}{l}\text { Faculty seemed to be highly interested in } \\
\text { content or outcomes of the project. }\end{array}$ & 4.6 & 2.4 & 2.2 & 11.000 & 0.000 & 0.180 \\
\hline $\mathrm{C}$ & $\begin{array}{l}\text { The group/team had members with the } \\
\text { necessary technical skills and abilities to } \\
\text { achieve the desired objective. }\end{array}$ & 4.8 & 2.6 & 2.2 & 5.880 & 0.002 & 0.635 \\
\hline E & $\begin{array}{l}\text { There was a sense of loyalty and dedication } \\
\text { to the team. }\end{array}$ & 4.8 & 2.6 & 2.2 & 3.773 & 0.010 & 1.192 \\
\hline E & $\begin{array}{l}\text { There was an unrestrained sense of } \\
\text { excitement and enthusiasm about the } \\
\text { group/team. }\end{array}$ & 4.8 & 2.6 & 2.2 & 3.773 & 0.010 & 1.192 \\
\hline
\end{tabular}




\begin{tabular}{|c|c|c|c|c|c|c|c|}
\hline Type $^{\text {a }}$ & Question & $\begin{array}{l}\text { Mean: } \\
\text { Team } \\
\text { Compet } \\
\text {-ition } \\
\end{array}$ & $\begin{array}{l}\text { Mean: } \\
\text { Class } \\
\text { Groups } \\
\end{array}$ & $\begin{array}{c}\text { Mean } \\
\text { Differ- } \\
\text { ence }\end{array}$ & t-stat & $p$ & Chi-sq \\
\hline $\mathrm{D}$ & $\begin{array}{l}\text { All members contributed in some way to } \\
\text { the effort. }\end{array}$ & 4.6 & 2.4 & 2.2 & 2.994 & 0.020 & 2.670 \\
\hline $\mathrm{B}$ & We held regularly scheduled meetings. & 4.8 & 2.6 & 2.2 & 2.994 & 0.020 & 2.280 \\
\hline I & $\begin{array}{l}\text { I would not prefer to carry out my next } \\
\text { project as an individual project }\end{array}$ & 4.8 & 2.6 & 2.2 & 2.269 & 0.043 & 3.917 \\
\hline $\mathrm{C}$ & $\begin{array}{l}\text { Too little thought was not put into } \\
\text { considering gender, race, age, or ability } \\
\text { when the groups were formed. }\end{array}$ & 4.4 & 2.4 & 2 & 3.162 & 0.017 & 1.195 \\
\hline $\mathrm{B}$ & $\begin{array}{l}\text { Our group had a consistent strategy } \\
\text { throughout the game. }\end{array}$ & 4.2 & 2.2 & 2 & 6.325 & 0.002 & 0.215 \\
\hline $\mathrm{I}$ & $\begin{array}{l}\text { I found it enjoyable to work with the } \\
\text { members of my group. }\end{array}$ & 4.8 & 2.8 & 2 & 3.162 & 0.017 & 1.436 \\
\hline $\mathrm{G}$ & $\begin{array}{l}\text { The group/team was supported by those } \\
\text { individuals and agencies outside the team } \\
\text { who were capable of contributing to the } \\
\text { team's success. }\end{array}$ & 4.2 & 2.2 & 2 & 3.162 & 0.017 & 1.603 \\
\hline $\mathrm{D}$ & $\begin{array}{l}\text { All members contributed creatively to the } \\
\text { effort. }\end{array}$ & 4.6 & 2.6 & 2 & 2.828 & 0.024 & 2.116 \\
\hline $\mathrm{E}$ & Our group was not disharmonious at times. & 4.2 & 2.4 & 1.8 & 3.087 & 0.018 & 1.063 \\
\hline $\mathrm{D}$ & Our team worked effectively together. & 4.8 & 3 & 1.8 & 3.087 & 0.018 & 1.168 \\
\hline $\mathrm{I}$ & $\begin{array}{l}\text { Working as a team on this project was a } \\
\text { positive experience. }\end{array}$ & 4.8 & 3 & 1.8 & 3.087 & 0.018 & 1.168 \\
\hline $\mathrm{C}$ & $\begin{array}{l}\text { The roles each group/team member were } \\
\text { responsible for were well matched to their } \\
\text { abilities. }\end{array}$ & 4.6 & 2.8 & 1.8 & 3.087 & 0.018 & 1.233 \\
\hline $\mathrm{D}$ & $\begin{array}{l}\text { There was a willingness to do anything that } \\
\text { had to be done to help the team succeed. }\end{array}$ & 4.8 & 3 & 1.8 & 3.087 & 0.018 & 1.168 \\
\hline $\mathrm{F}$ & $\begin{array}{l}\text { Within the group/team there was a sense of } \\
\text { honesty and integrity, with no lies, and no } \\
\text { exaggerations. }\end{array}$ & 4.8 & 3 & 1.8 & 3.087 & 0.018 & 1.168 \\
\hline I & $\begin{array}{l}\text { On the whole, I enjoy the experience of } \\
\text { group work }\end{array}$ & 4.6 & 2.8 & 1.8 & 2.092 & 0.052 & 2.819 \\
\hline $\mathrm{C}$ & $\begin{array}{l}\text { Individuals routinely completed their } \\
\text { assigned work. }\end{array}$ & 4.4 & 2.8 & 1.6 & 3.138 & 0.017 & 1.002 \\
\hline $\mathrm{B}$ & $\begin{array}{l}\text { Too little thought was not put into } \\
\text { considering conflicts in schedules of the } \\
\text { group members when the groups were } \\
\text { formed. }\end{array}$ & 4.4 & 2.8 & 1.6 & 3.138 & 0.017 & 1.678 \\
\hline $\mathrm{C}$ & $\begin{array}{l}\text { Our group/team members had fairly well } \\
\text { defined roles for each member. }\end{array}$ & 4.4 & 2.8 & 1.6 & 2.359 & 0.039 & 1.536 \\
\hline $\mathrm{B}$ & $\begin{array}{l}\text { Too much time was not spent in } \\
\text { negotiating differences of opinion in } \\
\text { formulating and writing up the group } \\
\text { research project. }\end{array}$ & 4.2 & 2.6 & 1.6 & 1.969 & 0.060 & 2.403 \\
\hline $\mathrm{I}$ & I would work in the same group again. & 4.8 & 3.2 & 1.6 & 3.138 & 0.017 & 0.830 \\
\hline A & Our group/team had a clear elevating goal. & 4.8 & 3.2 & 1.6 & 3.138 & 0.017 & 0.830 \\
\hline $\mathrm{H}$ & $\begin{array}{l}\text { The group/team leaders were not unwilling } \\
\text { to deal directly and effectively with self- } \\
\text { serving or noncontributing team members. }\end{array}$ & 4.6 & 3 & 1.6 & 3.138 & 0.017 & 0.920 \\
\hline $\mathrm{F}$ & $\begin{array}{l}\text { The group/team had recognizable standards } \\
\text { of excellence. }\end{array}$ & 4.8 & 3.2 & 1.6 & 2.667 & 0.028 & 1.243 \\
\hline
\end{tabular}




\begin{tabular}{|c|c|c|c|c|c|c|c|}
\hline Type $^{\text {a }}$ & Question & $\begin{array}{l}\text { Mean: } \\
\text { Team } \\
\text { Compet } \\
\text {-ition } \\
\end{array}$ & $\begin{array}{l}\text { Mean: } \\
\text { Class } \\
\text { Groups }\end{array}$ & $\begin{array}{c}\text { Mean } \\
\text { Differ- } \\
\text { ence }\end{array}$ & t-stat & $p$ & Chi-sq \\
\hline G & $\begin{array}{l}\text { The group/team had recognizable external } \\
\text { support and recognition. }\end{array}$ & 4.6 & 3 & 1.6 & 2.667 & 0.028 & 1.194 \\
\hline $\mathrm{E}$ & $\begin{array}{l}\text { It is easy to talk openly to all members of } \\
\text { my team. }\end{array}$ & 4.6 & 3 & 1.6 & 2.359 & 0.039 & 1.452 \\
\hline $\mathrm{A}$ & $\begin{array}{l}\text { I had a belief that the goal embodied a } \\
\text { worthwhile or important result. }\end{array}$ & 4.8 & 3.2 & 1.6 & 2.359 & 0.039 & 1.863 \\
\hline $\mathrm{D}$ & $\begin{array}{l}\text { There was an intense identification with a } \\
\text { group of people on the group/team. }\end{array}$ & 4.4 & 3 & 1.4 & 2.746 & 0.026 & 0.915 \\
\hline $\mathrm{H}$ & $\begin{array}{l}\text { One group member did not make most of } \\
\text { the decisions for our group. }\end{array}$ & 4.2 & 2.8 & 1.4 & 2.333 & 0.040 & 1.270 \\
\hline $\mathrm{D}$ & $\begin{array}{l}\text { Our team developed cohesiveness as the } \\
\text { project progressed. }\end{array}$ & 4.8 & 3.4 & 1.4 & 3.500 & 0.012 & 0.428 \\
\hline D & $\begin{array}{l}\text { My team members worked very well } \\
\text { together. }\end{array}$ & 4.8 & 3.4 & 1.4 & 2.746 & 0.026 & 0.837 \\
\hline$E$ & Communication in my group is very open. & 4.8 & 3.4 & 1.4 & 2.746 & 0.026 & 0.837 \\
\hline $\mathrm{B}$ & We kept minutes of each meeting. & 2.8 & 1.4 & 1.4 & 2.746 & 0.026 & 0.900 \\
\hline $\mathrm{E}$ & $\begin{array}{l}\text { Within the group/team there was an } \\
\text { openness-a willingness to share, and a } \\
\text { receptivity to information, perceptions, } \\
\text { ideas. }\end{array}$ & 4.8 & 3.4 & 1.4 & 2.746 & 0.026 & 0.837 \\
\hline $\mathrm{H}$ & $\begin{array}{l}\text { The group/team leader engaged and } \\
\text { motivated the team to succeed. }\end{array}$ & 4.6 & 3.2 & 1.4 & 2.746 & 0.026 & 0.949 \\
\hline $\mathrm{B}$ & $\begin{array}{l}\text { Each member's relationship to the } \\
\text { group/team was defined in terms of the } \\
\text { role to be assumed and the results the role } \\
\text { was to produce. }\end{array}$ & 4.4 & 3.2 & 1.2 & 2.449 & 0.035 & 0.754 \\
\hline $\mathrm{B}$ & We assigned roles for each meeting. & 4 & 2.8 & 1.2 & 2.058 & 0.054 & 1.129 \\
\hline B & $\begin{array}{l}\text { Too much time was not spent in scheduling } \\
\text { and meeting as a group }\end{array}$ & 4 & 2.8 & 1.2 & 1.395 & 0.118 & 2.669 \\
\hline I & $\begin{array}{l}\text { Substantial problems did not arise from } \\
\text { working in the group }\end{array}$ & 4.8 & 3.6 & 1.2 & 2.449 & 0.035 & 0.778 \\
\hline B & $\begin{array}{l}\text { Our group/team had a results-driven } \\
\text { structure. }\end{array}$ & 4.2 & 3.2 & 1 & 3.162 & 0.017 & 0.421 \\
\hline B & $\begin{array}{l}\text { One member did not do all the creative } \\
\text { work. }\end{array}$ & 4.2 & 3.2 & 1 & 2.236 & 0.045 & 0.783 \\
\hline D & $\begin{array}{l}\text { Personal success was not more important } \\
\text { than the group goal. }\end{array}$ & 4.2 & 3.2 & 1 & 2.236 & 0.045 & 0.534 \\
\hline $\mathrm{E}$ & $\begin{array}{l}\text { The opinions of all team members were } \\
\text { equally considered and respected. }\end{array}$ & 4.6 & 3.6 & 1 & 3.162 & 0.017 & 0.259 \\
\hline D & $\begin{array}{l}\text { There was a collaborative climate on the } \\
\text { group/team. }\end{array}$ & 4.6 & 3.6 & 1 & 3.162 & 0.017 & 0.259 \\
\hline $\mathrm{E}$ & $\begin{array}{l}\text { Within the group/team there was a respect } \\
\text { in treating people with dignity and fairness. }\end{array}$ & 4.6 & 3.6 & 1 & 3.162 & 0.017 & 0.259 \\
\hline D & $\begin{array}{l}\text { My group valued consensus in making } \\
\text { decisions. }\end{array}$ & 4.6 & 3.6 & 1 & 2.236 & 0.045 & 0.509 \\
\hline D & $\begin{array}{l}\text { Within the group/team there was a } \\
\text { consistency of predictable behavior and } \\
\text { responses. }\end{array}$ & 4.2 & 3.4 & 0.8 & 2.138 & 0.050 & 0.505 \\
\hline
\end{tabular}




\begin{tabular}{|c|c|c|c|c|c|c|c|}
\hline Type $^{\text {a }}$ & Question & $\begin{array}{l}\text { Mean: } \\
\text { Team } \\
\text { Compet } \\
\text {-ition } \\
\end{array}$ & $\begin{array}{l}\text { Mean: } \\
\text { Class } \\
\text { Groups } \\
\end{array}$ & $\begin{array}{c}\text { Mean } \\
\text { Differ- } \\
\text { ence }\end{array}$ & t-stat & $p$ & Chi-sq \\
\hline $\mathrm{E}$ & $\begin{array}{l}\text { One member of our team could not have } \\
\text { done a better job alone. }\end{array}$ & 4.4 & 3.6 & 0.8 & 1.372 & 0.121 & 1.031 \\
\hline $\mathrm{E}$ & $\begin{array}{l}\text { I was comfortable voicing my opinion, } \\
\text { even if it was different from other group } \\
\text { members. }\end{array}$ & 4.6 & 3.8 & 0.8 & 4.000 & 0.008 & 0.096 \\
\hline $\mathrm{G}$ & $\begin{array}{l}\text { The group/team was given the resources it } \\
\text { needed to get the job done. }\end{array}$ & 4.6 & 3.8 & 0.8 & 2.138 & 0.050 & 0.344 \\
\hline A & $\begin{array}{l}\text { I had a clear understanding of the goal to } \\
\text { be achieved. }\end{array}$ & 4.8 & 4 & 0.8 & 1.372 & 0.121 & 1.042 \\
\hline $\mathrm{D}$ & We subdivided work effectively. & 4.2 & 3.8 & 0.4 & 1.633 & 0.089 & 0.154 \\
\hline $\mathrm{E}$ & $\begin{array}{l}\text { Within the group/team there was a one } \\
\text { team member would pick up any slack that } \\
\text { occurred when another member falters. }\end{array}$ & 3.8 & 3.6 & 0.2 & 1.000 & 0.187 & 0.084 \\
\hline
\end{tabular}

* Indicates significant at the 5\% level (one-tail t-test or chi-square test).

** Indicates significant at the $10 \%$ level (one-tail t-test).

\section{${ }^{\text {a }}$ Type}

Questions are assigned to nine types based on the eight characteristics of effectively functioning teams identified by Larson and LaFasto (1989) and an additional category relating to overall satisfaction with the group learning experience.
(A) A clear, elevating goal,
(B) Results-driven structure,
(C) Competent team members,
(D) Unified commitment,
(E) Collaborative climate,
(F) Standards of excellence,
(G) External support and recognition,
(H) Principled leadership, and
(I) Satisfaction with the group learning experience. 
NOTES 